\title{
PENGARUH CAREER DEVELOPMENT DAN ORGANIZATIONAL CULTURE TERHADAP JOB SATISFACTION SERTA DAMPAKNYA PADA EMPLOYEE PERFORMANCE
}

\author{
Johan Yuda Prawira Putra \\ Universitas Negeri Surabaya \\ johanprawira12@gmail.com
}

\begin{abstract}
The purpose of this study is to identify and test the effect of career development and organizational culture on performance through job satisfaction in banking employees in the South Jakarta area. 38 employees were participating, while the questionnaire processed using Partial Least Square. The results prove organizational culture and career development can influence the level of employee satisfaction. Next, if seen from its influence on performance, only organizational culture affects, while satisfaction and career development do not affect. If based on its influence through job satisfaction, organizational culture and career development do not affect. The implication that can be practiced by companies is objectivity in promotion with based on aspects of performance and optimize organizational culture that has been applied in the company and researchers suggest that companies can create programs that can increase dedication, loyalty, and employee commitment to work such as providing rewards, providing clear career paths, and better HR management.
\end{abstract}

Keywords: career development; employee performance; job satisfaction; organizational culture.

\section{PENDAHULUAN}

Karyawan merupakan bagian dari sumber daya yang berkontribusi penting dalam proses operasional perusahaan (Sutrisno, 2009, p. 2). Hal serupa juga diungkapkan oleh Veithzal \& Sagala (2011), di mana perkembangan bisnis dalam suatu perusahaan ditentukan oleh seberapa besar output yang dihasilkan karyawan. Performance pada umumnya adalah tujuan akhir yang penting dan memiliki pengaruh terhadap perusahaan. Menurut Dewi et al., (2014), job satisfaction merupakan perilaku yang merasa cukup puas maupun tidak yang dimiliki karyawan atas penilaian yang diberikan oleh atasan tekait tanggungjawabnya dalam bekerja. Individu atau karyawan yang tidak memiliki rasa puas dapat menjadi suatu masalah dalam perusahaan, karena akan mengganggu tercapainya kinerja yang lebih baik. Berdasarkan sudut individu tersebut, rasa tidak puas akan berdampak negatif terhadap motivasi, moril, dan ketrampilan baik secara kualitas maupun hasil (Hasibuan \& Afrizal, 2019).

Berdasarkan penelitian Putra et al., (2019) pada 61 dosen di 3 Fakultas di Universitas Tabanan Bali menghasilkan job satisfaction berpengaruh signifikan pada employee performance. Sejalan dengan hasil tersebut, dalam penelitian Sathyanarayan \& Lavanya (2018) terhadap 163 karyawan TI di Kota Chennai yang hasilnya terdapat dampak yang sigifikan. Hasil lain yang sama juga terdapat pada penelitian Fu \& Deshpande (2014), Kawiana et al., (2018) dan Sari \& Susilo (2018). Hal ini berbanding terbalik dengan hasil penelitian Pawirosumarto et al., (2017), Arda (2017), Subakti (2013) dan Hidayati \& Rahmawati (2016), di mana hasilnya adalah job satisfaction tidak berpengaruh signifikan pada employee performance.

Adanya career development, individu memiliki kesempatan untuk dapat meningkatkan Skill dan Knowledge yang dimiliki dalam menjalankan peran dan fungsi serta tanggungjawab dalam bekerja (Setiyaningrum, 2019). Hal ini dibuktikan oleh Ali et al., (2019) terhadap 585 responden bank komersial di Pakistan di mana career development berpengaruh pada employee performance. Penelitian lain yang sama juga terdapat pada penelitian Nasution et al., (2018) dan Suryadani (2016). Berbanding terbalik dengan hasil tersebut, hasil penelitian dari Putri \& Frianto (2019), Khotimah (2014), dan Saputra \& Hendriani (2015) beserta Setiyaningrum (2019), membuktikan tidak terdapat pengaruh yang signifikan. Kemudian berdasarkan pengaruhnya pada job satisfaction, menurut hasil dari Jusuf et al., (2016) menyatakan career development berdampak signifikan pada job satisfaction. Hasil tersebut juga didukung oleh Shujaat et al., (2013), Jufrizen (2015) beserta Aritonang et al., (2019). Namun, menurut Kaya \& Ceylan (2014) terhadap 204 karyawan di Provinsi Istanbul Turki 
Johan Yuda Prawira Putra. Pengaruh Career Development dan Organizational Culture terhadap Job Satisfaction serta Dampaknya pada Employee Performance

menghasilkan tidak adanya pengaruh pada tingkat satisfaction. Hasil tersebut didukung oleh Alif (2015), Manoppo (2015) dan Maghfiroh \& Djati (2017).

Organizational culture yang berjalan dalam organisasi juga menentukan kinerja karyawan. Menurut Nazir \& Zamir (2015), organizational culture yang berjalan di organisasi ada pengaruhnya terhadap employee performance. Hasil penelitian Kahumburu et al., (2017) terhadap 130 responden yang bekerja pada Scripture Union di Kenya menunjukkan bahwa organizational culture memiliki hubungan positif pada performance dari masing-masing individu. Demikian pula penelitian Batcha et al., (2017), dan Widjaja (2017), Kawiana et al., (2018) serta Utari et al., (2018) yang memiliki hasil serupa dalam penelitiannya. Berbanding terbalik dengan hasil Nusari et al., (2018) terhadap 539 responden di badan usaha milik negara (SoE) Abu Dhabi, jika organizational culture (individualisme) berdampak negatif pada performance secara kualitas, sedangkan Putriana et al., (2015), Andi et al., (2019) beserta Syauta et al., (2012) yang menyatakan organizational culture yang ada tidak berdampak pada performance. Kemudian research yang dihasilkan oleh Habib et al., (2014) pada 235 pegawai di kota Punjab, Pakistan yang hasilnya adalah organizational culture berpengaruh signifikan terhadap job satisfaction. Hasil tersebut didukung oleh Meng \& Berger (2019), Qazi \& Kaur (2017), Putriana et al., (2015), dan Alvi et al., (2014), sedangkan Andi et al., (2019) menyatakan tidak mempunyai pengaruh secara signifikan.

Berdasarkan hasil survei tingkat kepuasan kerja terhadap karyawan bank (BRI, Bank Mandiri, BNI, dan BCA) yang dilakukan oleh Jobplanet.com (2016), diketahui sebanyak \pm 7.000 karyawan perbankan ikut berpartisipasi dalam survei tersebut. Kemudian untuk tingkat kepuasan karyawan tersebut diukur melalui rentang rating satu hingga lima. Di mana skala rating satu "sangat tidak puas" hingga skala rating lima "sangat puas". Hasil survey tersebut menunjukkan tingkat kepuasan karyawan dari 4 perbankan secara berturut-turut dari yang tertinggi adalah karyawan BCA dengan rating $(4,1)$, karyawan BNI dengan rating $(3,7)$, karyawan Mandiri dengan rating $(3,6)$, dan karyawan BRI dengan rating $(3,5)$. Rata-rata tingkat kepuasan dari 4 perbankan tersebut berada pada rating 3 dengan tolak ukur indikator gaji, keseimbangan kehidupan kerja, manajemen, budaya organisasi, dan jenjang karir. Selanjutnya penjabaran tingkat kepuasan karyawan dari keempat bank bedasarkan indikator digambarkan pada gambar 1.

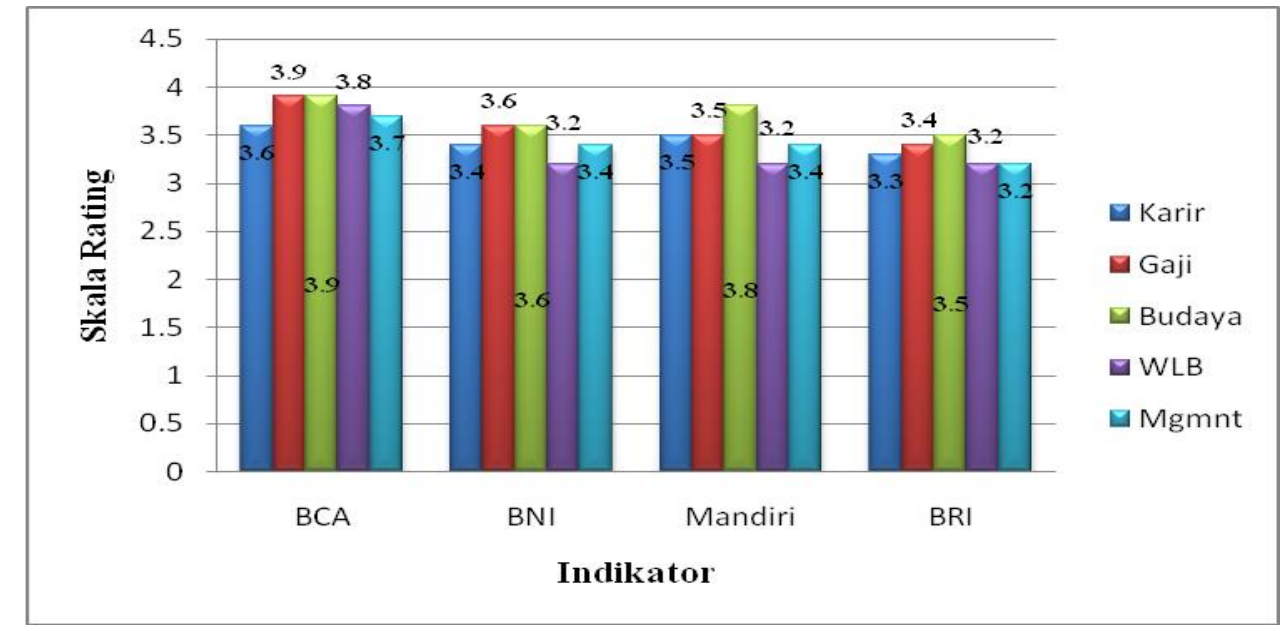

Sumber: Jobplanet.com (2016, data diolah)

\section{Gambar 1. GRAFIK TINGKAT KEPUASAN KARYAWAN PERBANKAN BERDASARKAN INDIKATOR}

Pada gambar 1, dapat diketahui bahwa tingkat kepuasan terhadap jenjang karir dan budaya diperusahaan BCA, BNI, Mandiri, dan BRI berada pada nilai skala rata-rata 3. Berdasarkan hasil wawancara terhadap Ibu LI selaku pegawai BNI yang telah bekerja selama 4 tahun dan menjabat sebagai assistant analysist, menyatakan bahwa beliau merasa masih belum puas terhadap pengembangan karir di perusahaan. Hal ini dikarenakan terdapat beberapa faktor ketidakadilan dalam mendapatkan promosi di mana harapan beliau untuk dapat memiliki jenjang karir diperusahaan 
kurang sesuai dengan ekspektasi terhadap pengembangan karir diperusahaan seperti, karyawan yang memiliki kedekatan dengan pimpinan akan lebih dprioritaskan untuk mendapatkan promosi daripada karyawan yang memiliki kinerja lebih baik. Sedangkan untuk budaya beliau menyatakan budaya kerja disesuaikan dengan SOP yang berlaku di perusahaan.

Berdasarkan hasil wawancara terhadap Ibu FN selaku pegawai administrasi yang telah bekerja selama 3 tahun di BCA, menyatakan bahwa beliau merasa masih belum puas terhadap pengembangan karir di perusahaan karena belum sesuai dengan harapan beliau. Berdasarkan hasil wawancara dengan Ibu LS selaku pegawai yang telah bekerja selama 4 tahun dan menjabat sebagai auditor di BRI, menyatakan bahwa beliau kurang puas dengan sistem karir dan budaya perusahaan tempat beliau bekerja. Berdasarkan hasil wawancara dengan Ibu KN selaku pegawai Bank Mandiri yang telah bekerja selama 4 tahun dan menjabat sebagai frontliner juga menyatakan bahwa beliau kurang puas dengan sistem karir sedangkan untuk budaya kerja yang ada di perusahaan memiliki tuntutan kerja cukup tinggi.

Penelitian ini bertujuan untuk mengidentifikasi dan menguji pengaruh career development dan organizational culture terhadap job satisfaction serta dampaknya pada employee performance pada karyawan perbankan wilayah Jakarta Selatan.

\section{KAJIAN PUSTAKA DAN PENGEMBANGAN HIPOTESIS}

\section{Career Development}

Langkah formal perusahaan untuk mewujudkan individu dengan skill dan knowledge terbaik akan tersedia di waktu tertentu (Hadiwijaya, 2016). Sedangkan menurut Kadarisman dalam Aritonang et al., (2019), career development bertujuan meningkatkan skill dan knowledge karyawan agar memiliki wawasan yang luas melalui kesempatan promosi di perusahaan. Menurut Siagian dalam Putri (2015), career development juga dapat didefinisikan kumpulan langkah-langkah yang disusun oleh individu dalam mencapai karir yang diharapkan dan yang telah direncanakan sebelumnya. Career development dari karyawan adalah pendekatan atau kegiatan yang tersusun secara formal untuk meningkatkan pertumbuhan, kepuasan kerja, pengetahuan, dan kemampuan pegawai agar organisasi dapat memastikan bahwa orang-orang dengan kualifikasi dan pengalaman yang cocok tersedia dalam organisasi (Manoppo, 2015). Usaha pembentukan career development yang dirancang dengan baik akan dapat membantu para karyawan dalam menentukan apa yang menjadi kebutuhan karir mereka sendiri dan menyesuaikan antara kebutuhan karyawan dengan tujuan perusahaan (Maghfiroh \& Djati, 2017). Sehingga dari pemaparan para ahli tersebut menunjukkan bahwa career development merupakan langkah formal yang digunakan perusahaan maupun individu untuk meningkatkan skill dan knowledge dalam mencapai karir yang telah direncanakan melalui kesempatan promosi.

\section{Organizational Culture}

Menurut Nazir \& Zamir (2015), organizational culture merupakan gabungan harapan, sejarah, dan peraturan yang ada di organisasi yang berpengaruh pada kinerja individu. Tidak jauh berbeda dengan definisi tersebut, menurut Sashkin \& Rosenbach (2013), organizational culture merupakan seperangkat nilai, kepercayaan dan peraturan yang dimiliki tiap perusahaan yang diatur secara bersama-sama untuk mencapai efektivitas dalam mewujudkan misi perusahaan. Menurut Robbins (2002:279), organizational culture menyangkut bagaimana para anggota melihat organisasi tersebut, bukan menyangkut apakah para anggota organisasi menyukainya atau tidak, karena para anggota menyerap organizational culture berdasarkan dari apa yang mereka lihat atau dengar di dalam organisasi. Sedangkan menurut Rahmi \& Mulyadi (2018), organizational culture adalah pola asumsi bersama yang dipelajari oleh suatu kelompok dalam memecahkan masalah melalui adaptasi eksternal dan integrasi internal, yang telah bekerja cukup baik untuk dipertimbangkan kebenarannya, oleh karena itu untuk diajarkan kepada karyawan baru cara yang benar untuk melihat, berpikir dan merasakan kaitannya dengan masalah-masalah yang ada. Sehingga dari pemaparan para ahli tersebut dapat diketahui bahwa organizational culture merupakan bagaimana asumsi anggota terhadap aturan, nilai, kepercayaan, dan keyakinan dasar yang digunakan untuk mengarahkan seluruh anggota 
Johan Yuda Prawira Putra. Pengaruh Career Development dan Organizational Culture terhadap Job Satisfaction serta Dampaknya pada Employee Performance

organisasi agar mengimplementasikan budaya tersebut secara efektif dalam praktik operasional perusahaan dan menjadi patokan dalam setiap pengambilan kebujakan.

\section{Job Satisfaction}

Menurut Asepta (2017), job satisfaction merupakan asumsi atau pandangan seseorang, baik yang positif maupun negatif dalam menilai kewajibannya dalam pekerjaan. Selain itu, job satisfaction didefinisikan sebagai rasa puas atau menyenangkan yang dirasakan seseorang atas pencapaian terhadap pekerjaannya. (Luthans, 2011). Pengertian tersebut sejalan dengan Manoppo (2015), yang mengemukakan bahwa job satisfaction kepuasan kerja merupakan perasaaan puas akan lingkungan kerja dan pekerjaan yang diterima oleh karyawan. Menurut Maslichah (2017), job satisfaction didefinisikan sebagai sikap emosional yang menyenangkan dan mencintai pekerjaannya. Oleh karena itu, job satisfaction harus diperhatikan oleh perusahaan, apabila karyawan merasa tidak puas dengan pekerjaannya, mereka akan meninggalkan pekerjaannya, sering mengeluh, membangkang, menghidari tanggung jawab pekerjaannya, dan lain sebagainya (Nurendra \& Saraswati, 2016). Pendapat yang sama juga dikemukakan oleh Robbins \& Judge (2015), job satisfaction adalah sebuah perasaan yang positif mengenai pekerjaan seseorang yang menjadi hasil dari sebuah evaluasi pekerjaan. Berdasarkan uraian para ahli di atas dapat diketahui jika job satisfaction, yaitu cara pandang yang positif maupun negatif serta suatu perasaan puas atau menyenangkan yang berasal dari pencapaian yang telah dilakukan seorang individu dalam menilai pekerjaannya atau tanggungjawabnya di perusahaan yang menjadi evaluasi atas suatu pekerjaan yang telah dilakukan oleh karyawan.

\section{Employee Performance}

Merupakan timbal balik dari usaha dan kontribusi yang telah diberikan seseorang atas jobdesk atau kewajiban dalam pekerjaannya (Khan et al., 2012). Sedangkan menurut Rehman et al., (2017), employee performance adalah suatu tindakan yang relevan dari seorang karyawan untuk melakukan yang harus dilakukan secara terus menerus dan akan meningkat ketika karyawan mencoba dan berhasil melakukan lebih cepat dan lebih baik sesuai instruksi yang telah diberikan. Employee performance juga merupakan output yang dihasikan karyawan atas beberapa hasil pencapain kerja yang diberikan sesuai dengan tanggungjawab yang telah diterimanya yang memiliki dampak terhadap individu dan organisasi (Mathis \& Jackson, 2008). Employee performance menurut Setiyaningrum (2019), didefinisikan sebagai hasil pekerjaan yang diberikan karyawan dan disesuaikan dengan ketentuan perusahaan. Sehingga dari pemaparan para ahli tersebut dapat diketahui bahwa employee performance merupakan timbal balik dari usaha dan kontribusi yang mampu dikerjakan atau dihasilkan (output) oleh seorang individu terhadap tugasnya sesuai dengan intruksi yang telah diberikan.

\section{Hubungan Antar Variabel}

Penelitian yang dilakukan oleh Jusuf et al., (2016) menunjukkan bahwa career development memiliki pengaruh positif terhadap job satisfaction. Penelitian lain yang menunjukkan hasil yang sama adalah Shujaat et al., (2013), Jufrizen, (2015), Aritonang et al., (2019) dan Saleem et al., (2013).

H1: Career development berpengaruh positif terhadap job satisfation di perbankan wilayah Jakarta Selatan.

Penelitian yang dilakukan oleh Ali et al., (2019) terhadap 585 karyawan perbankan tetap di cabang bank komersial yang terletak di kota besar di Pakistan yang menunjukkan hasil bahwa career development berpengaruh signifikan pada employee performance. Penelitian lain yang menunjukkan hasil yang sama adalah Nasution et al., (2018) dan Suryadani (2016).

H2: Career development berpengaruh positif terhadap employee performance di perbankan wilayah Jakarta Selatan.

Penelitian yang dilakukan oleh Habib et al., (2014) terhadap 235 karyawan yang bekerja di organisasi yang berbeda dalam wilayah Multan wilayah Punjab, Pakistan yang menunjukkan hasil bahwa organizational culture berpengaruh signifikan terhadap job satisfaction. Hasil yang sama juga 
ditunjukkan dalam penelitian yang dilakukan oleh Meng \& Berger (2019) terhadap karyawan yang bekerja di berbagai organisasi sebagai Public Relation di AS bahwa organizational culture memiliki dampak yang signifikan terhadap job satisfaction. Penelitian lain yang menunjukkan hasil yang sama adalah Bigliardi et al., (2012), Alvi et al., (2014), dan Putriana et al., (2015) serta Ilham (2017).

H3: Organizational culture berpengaruh positif terhadap job satisfaction di perbankan wilayah Jakarta Selatan.

Penelitian yang dilakukan oleh Kahumburu et al., (2017) terhadap 130 karyawan yang bekerja pada Scripture Union di Kenya menunjukkan bahwa organizational culture memiliki hubungan positif terhadap employee performance. Hasil yang sama juga ditunjukkan dalam penelitian yang dilakukan oleh Batcha et al., (2017), Kawiana et al., (2018), Ugwu et al., (2017), dan Utari et al., (2018), Widjaja (2017) serta Nazir \& Zamir (2015).

H4: Organizational culture berpengaruh positif terhadap employee performance di perbankan wilayah Jakarta Selatan.

Penelitian yang dilakukan oleh Sathyanarayan \& Lavanya (2018) terhadap 163 karyawan yang bekerja di sektor teknologi informasi di Kota Chennai yang menunjukkan bahwa job satisfaction berdampak positif pada employee performance. Penelitian lain yang menunjukkan hasil yang sama adalah Fu \& Deshpande (2014), Kawiana et al., (2018), Sari \& Susilo (2018), dan Putra et al., (2019).

H5: Job satisfation berpengaruh positif terhadap employee performance di perbankan wilayah Jakarta Selatan.

Penelitian yang dilakukan oleh Setiyaningrum (2019) terhadap karyawan tetap yang bekerja di PT. PLN (Persero) Unit Induk Distribusi Jawa Timur UP3 Ponorogo menunjukkan bahwa job satisfaction memediasi pengaruh career development terhadap employee performance.

H6: Career development berpengaruh positif terhadap employee performance melalui job satisfation di perbankan wilayah Jakarta Selatan.

Penelitian yang dilakukan oleh Syauta et al., (2012) terhadap 127 yang bekerja di Municipal Waterworks of Jayapura, Papua Indonesia menunjukkan bahwa job satisfaction memediasi pengaruh organizational culture terhadap employee performance. Penelitian lain yang menunjukkan hasil yang sama adalah Sulaiman et al., (2014). Hubungan antar variabel juga dapat dilihat di Gambar 2.

H7: Organizational culture berpengaruh positif terhadap employee performance melalui job satisfation di perbankan wilayah Jakarta Selatan.

\section{METODE PENELITIAN}

Karyawan yang berpartisipasi adalah karyawan perbankan di BRI, Bank Mandiri, BNI, dan BCA wilayah Jakarta Selatan yang berlangsung selama satu bulan (April-Mei) dengan ukuran sampel secara keseluruhan adalah 38 dengan pengambilan sample menggunakan teknik non probabilitas sampling, yaitu sampling jenuh. Kemudian untuk mengumpulkan data dilakukan dengan studi literatur (berita maupun artikel) serta melakukan wawancara dari berbagai sumber dan menyebarkan kuisioner melalui Google Form dan telepon secara online kepada karyawan yang bekerja di 4 perbankan, diantaranya BRI, Bank Mandiri, BNI, dan BCA wilayah Jakarta Selatan yang secara keseluruhan dari 4 perbankan tersebut berjumlah 38 responden. Kemudian Partial Least Square digunakan sebagai analisis data, sedangkan likert scale dipakai sebagai tolak ukur terhadap hasil kuisioner responden. Selanjutnya pengukuran career development, organizational culture, job satisfaction, dan employee performance dideskripsikan dalam gambar 2. 
Johan Yuda Prawira Putra. Pengaruh Career Development dan Organizational Culture terhadap Job Satisfaction serta Dampaknya pada Employee Performance

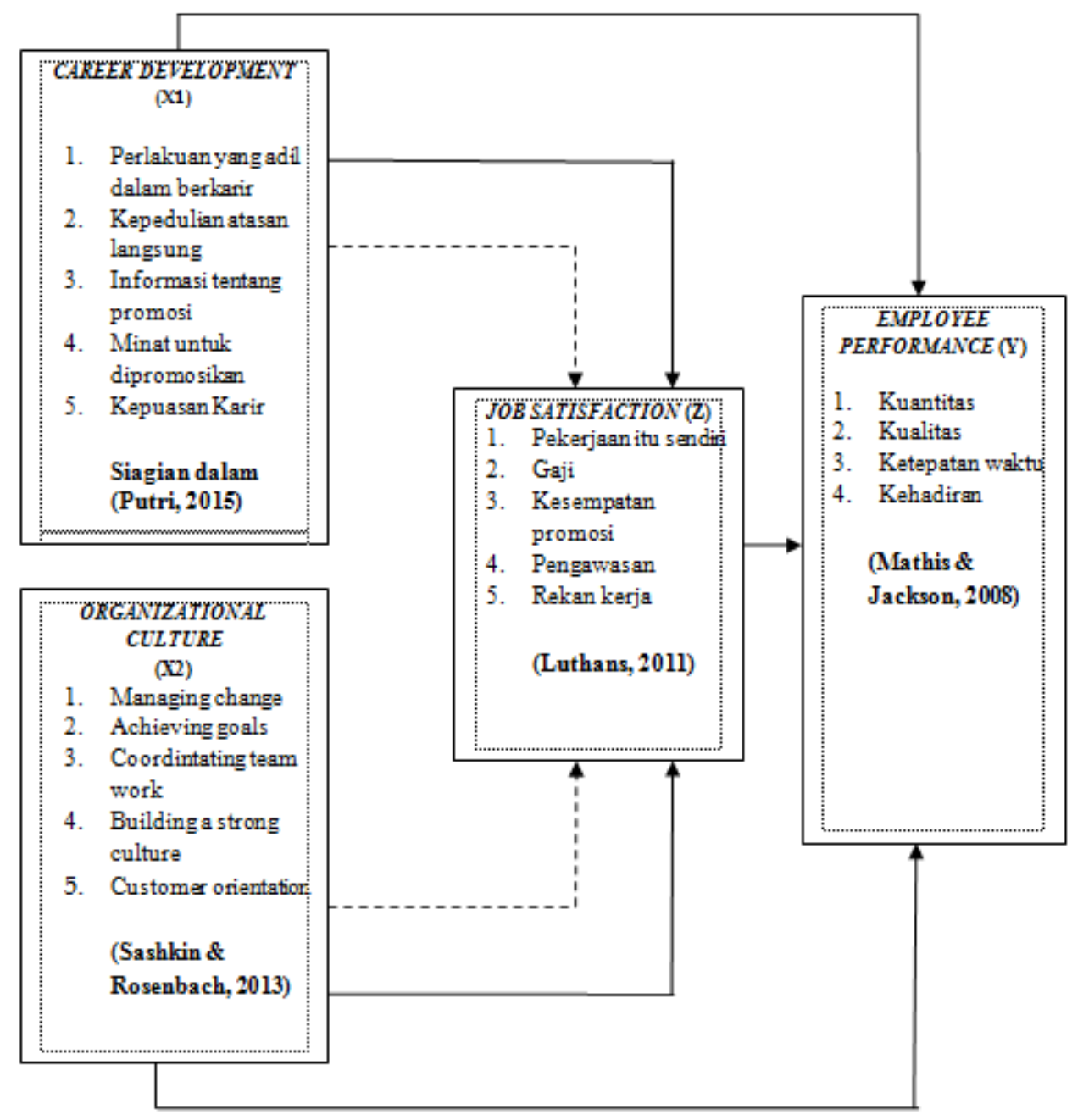

Gambar 2. KERANGKA PENELITIAN

\section{HASIL DAN PEMBAHASAN}

\section{Karakteristik Responden}

Gambaran karyawan yang berpartisipasi adalah karyawan perbankan di BRI, Bank Mandiri, BCA, dan BNI wilayah Jakarta Selatan yang mayoritas adalah perempuan $(63,2 \%)$ dengan usia rata-rata $\leq$ 30 tahun sebanyak 37 orang $(97,4 \%)$. Selanjutnya sebagian besar responden berpendidikan S1 $(63,2 \%)$ dan sebagian besar berstatus belum menikah $(65,8 \%)$ serta mayoritas memiliki masa kerja $\leq$ 5 tahun $(84,2 \%)$. Kemudian berdasarkan nama perbankan, sebesar $(18,4 \%)$ responden bekerja di BRI, sebesar $(15,8 \%)$ bekerja di Bank Mandiri, dan sebesar $(44,7 \%)$ bekerja di BNI serta sebesar $(21,1 \%)$ responden bekerja di BCA.

\section{Convergent Validity}

Dari hasil pengujian terhadap kevaliditasan dari keseluruhan indicator, terlihat bahwa semua bernilai di atas atau melebihi standar minimal validity yang ditetapkan oleh Ghozali (2013). Sehingga dengan demikian dapat dikatakan valid. Hasil lebih detail dapat dilihat di Gambar 3.

\section{Composite Reliability}

Composite Realibity (CR) dapat dikatakan baik apabila nilainya melebihi standar yang telah ditetapkan Ghozali (2013), yaitu 0,70. Jika melihat hasil di atas, keseluruhan variabel telah di atas standar yang telah ditetapkan. Sehingga dapat dikatakan realibel. Hasil lebih detail dapat dilihat di Tabel 1. 


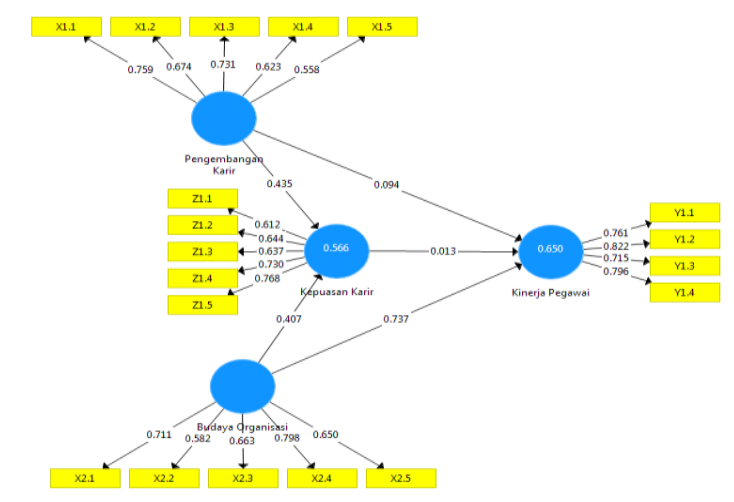

Sumber: Output SmartPLS3 (data diolah)

Gambar 3. UJI MEASUREMENT MODEL

Tabel 1. COMPOSITE RELIABILITY

\begin{tabular}{lc}
\hline \multicolumn{1}{c}{ Variable } & Composite Reliabilty \\
\hline Career Development & 0,804 \\
Organizational Culture & 0,813 \\
Job Satisfaction & 0,811 \\
Employee Performance & 0,857 \\
\hline
\end{tabular}

Sumber: Output SmartPLS3 (data diolah)

\section{Cronbach's Alpha}

Suatu research awal yang ditujukan untuk mencapai studi akhir, standar minimal dari CA (Croanbach's Alpha), yaitu 0,60. Hal ini sebagaimana yang diungkapkan Siregar (2017). Data di tabel 2 menunjukkan semua konstruk sudah sesuai dengan standar minimal yang telah ditetapkan.

Tabel 2. CRONBACH'S ALPHA

\begin{tabular}{lc}
\hline \multicolumn{1}{c}{ Variable } & Cronbach's Alpha \\
\hline Career Development & 0,694 \\
Organizational Culture & 0,712 \\
Job Satisfaction & 0,708 \\
Employee Performance & 0,778 \\
\hline
\end{tabular}

Sumber: Output SmartPLS3 (data diolah)

\section{R-Square}

Diketahui nilai $R$ Square job satisfaction adalah 0,566 sehingga hasil tersebut dapat dijelaskan bahwa kedua variabel eksogen tersebut dapat menjelaskan pengaruhnya pada job satisfaction sebesar 56,6\%. Sementara variabel lain yang tidak terdapat di research ini dapat menjelaskan pengaruhnya sebesar $43,4 \%$. Selanjutnya berdasarkan hasil pengujian, dapat ketahui untuk nilai $R$ Square employee performance adalah 0,650 sehingga jika melihat hasil tersebut dapat dijelaskan bahwa kedua variabel eksogen tersebut mampu untuk menjelaskan pengaruhnya pada employee performance sebesar $65,5 \%$. Sementara Sementara 34,5\% diuraikan oleh variabel yang tidak ada di research ini.

\section{Path Coefficients}

Pada tabel 3, dapat diketahui bahwa pengaruh career development terhadap job satisfaction karyawan di perbankan wilayah Jakarta Selatan memiliki nilai $t$-statistics 2,276. Hasil tersebut memiliki nilai yang lebih tinggi atau lebih besar dari 1,96. Selanjutnya apabila koefisien estimate memiliki nilai 0,435 , artinya career development terhadap job satisfaction karyawan adalah searah. Jika career 
Johan Yuda Prawira Putra. Pengaruh Career Development dan Organizational Culture terhadap Job Satisfaction serta Dampaknya pada Employee Performance

development semakin baik, maka apa yang dirasakan karyawan mengenai job satisfaction akan dapat semakin baik. Kemudian ini juga berlaku apabila nilai career development rendah. Sehingga dapat diketahui bahwa career development berpengaruh signifikan dan berdampak searah terhadap job satisfaction. Kemudian pengaruh career development terhadap employee perforamance perbankan di wilayah Jakarta Selatan diketahui jumlah hasil t-statistics ialah 0,754, dengan angka tersebut menunjukkan jika rendah dari 1,96 . Sehingga menujukkan tidak ada pengaruh yang siginifikan dari career development terhadap employee perforamance, maka dengan hasil tersebut tidak perlu untuk melihat pada koefisien estimate karena setinggi atau serendah apapun career development tidak berpengaruh pada employee perforamance.

Tabel 3.

PATH COEFFICIENTS

\begin{tabular}{|c|c|c|c|c|}
\hline $\begin{array}{c}\text { Hubungan } \\
\text { Antar Variabel }\end{array}$ & $\begin{array}{l}\text { Original } \\
\text { Sample }\end{array}$ & $\begin{array}{c}T- \\
\text { Statistics } \\
\end{array}$ & Keterangan & Hasil \\
\hline$C D \rightarrow J S$ & 0,435 & 2,276 & $\geq 1,96$ (Sig.) & $\begin{array}{c}\text { Hipotesis } \\
\text { Diterima }\end{array}$ \\
\hline$C D \rightarrow E P$ & 0,094 & 0,754 & $\begin{array}{c}\leq 1,96 \\
\text { (Tidak Sig.) }\end{array}$ & $\begin{array}{c}\text { Hipotesis } \\
\text { Ditolak }\end{array}$ \\
\hline$O C \rightarrow J S$ & 0,407 & 2,375 & $\geq 1,96$ (Sig.) & $\begin{array}{c}\text { Hipotesis } \\
\text { Diterima }\end{array}$ \\
\hline$O C \rightarrow E P$ & 0,737 & 3,520 & $\geq 1,96$ (Sig.) & $\begin{array}{c}\text { Hipotesis } \\
\text { Diterima }\end{array}$ \\
\hline$J S \rightarrow E P$ & 0,013 & 0,052 & $\begin{array}{c}\leq 1,96 \\
\text { (Tidak Sig.) }\end{array}$ & $\begin{array}{c}\text { Hipotesis } \\
\text { Ditolak }\end{array}$ \\
\hline
\end{tabular}

Sumber: Output SmartPLS3 (data diolah)

Selanjutnya untuk variabel budaya terhadap job satisfaction diketahui nilai dari $t$-statisticsnya adalah 2,375 dan lebih tinggi dari standar minimalnya $(1,96)$. Jika melihat dari hasil dengan nilai koefisien estimate diketahui 0,407 dan menunjukkan bahwa organizational culture ada pengaruh yang signifikan pada job satisfaction dan dapat diketahui jika organizational culture yang diimplementasikan oleh suatu organisasi itu tinggi, tingkat job satisfaction karyawan akan semakin tinggi. Sementara untuk nilai $t$-statistics organizational culture terhadap employee perforamance, yaitu sebesar 3,520 dan lebih tinggi dari 1,96, sementara itu, nilai koefisien estimatenya ialah 0,737 (positif). Sehingga dilihat dari hasil $t$-statistics dan koefisien estimate, menunjukkan jika organizational culture memiliki dampak yang searah pada employee perforamance. Berikutnya untuk nilai $t$-statistics job satisfaction terhadap employee perforamance diketahui sebesar 0,052 , yang berarti job satisfaction tidak mampu untuk memengaruhi kondisi employee perforamance perbankan di wilayah Jakarta Selatan. Hal ini juga memperlihatkan bahwa, setinggi apapun job satisfaction yang dirasa oleh pegawai, employee perforamance tidak akan terpengaruh.

\section{Indirect Effect}

Nilai $t$-statistics berdasarkan hasil pengujian untuk (indirect effect) career development terhadap employee performance 0,040 dan kurang dari 1,96, maka menunjukkan bahwa career development tidak berpengaruh pada employee performance apabila dimediasi job satisfaction. Selanjutnya berdasarkan hasil pengujian, untuk mengetahui (indirect effect) dari organizational culture mengenai dampaknya terhadap employee performance apabila melalui mediasi dari job satisfaction adalah 0,049 dan kurang dari standar minimalnya $(1,96)$. Dengan demikian dapat diambil makna bahwa organizational culture terhadap employee performance tidak memiliki dampak jika melalui mediasi.

\section{Pengaruh Career Development terhadap Job Satisfaction}

Berdasarkan penjelasan sebelumnya terkait hasil dari pengujian hipotesis career development terhadap job satisfaction menunjukkan hasilnya adalah $\mathrm{H} 1$ diterima. Kemudian dari hasil wawancara terhadap beberapa karyawan perbankan (BRI, Bank Mandiri, BNI, dan BCA) di wilayah Jakarta 
Selatan menunjukkan bahwa karyawan dari keempat bank tersebut memiliki jawaban yang sama, yaitu kurang puas terhadap sistem career development di perusahaan. Hal ini dikarenakan posisi yang saat ini belum sesuai dengan harapan dari masing-masing karyawan, serta dari hasil wawancara tersebut diketahui bahwa program karir di perusahaan masih kurang objektif yang disebabkan masih terdapat ketidakadilan dalam memperoleh promosi jabatan yang diberikan oleh atasan. Karyawan yang memiliki kedekatan yang baik dengan atasan memiliki prioritas dalam hal mendapatkan promosi. Sementara karyawan dengan kinerja yang lebih baik, namun tidak memiliki kedekatan yang baik dengan atasan akan menjadi kurang diprioritaskan dalam mendapat promosi jabatan. Berdasarkan hasil wawancara juga menunjukkan bahwa karyawan di empat perbankan tersebut memiliki minat atau keinginan yang tinggi untuk dapat meningkatkan jenjang karir. Sehingga dengan demikian mendukung research Jusuf et al., (2016), Jufrizen (2015), Budy \& Hartini (2017), dan Saleem et al., (2013), Aritonang et al., (2019) serta Shujaat et al., (2013).

\section{Pengaruh Career Development terhadap Employee Performance}

Berdasarkan penjelasan sebelumnya terkait hasil dari pengujian hipotesis career development terhadap employee performance menunjukkan hasil bahwa $\mathrm{H} 2$ ditolak, yang artinya tidak ada pengaruh career development beserta dampaknya pada employee performance. Berdasarkan hasil wawancara terhadap beberapa karyawan BRI, Bank Mandiri, BNI, dan BCA menyatakan bahwa career development bukan faktor utama yang memengaruhi employee performance, namun terdapat hal utama lainnya yang paling berpengaruh pada employee performance diantaranya, kerjasama tim, dedikasi dalam diri, loyalitas, dan komitmen dalam bekerja. Selain itu, dukungan yang diberikan oleh organisasi dalam bentuk seperti fasilitas pekerjaan dan tunjangan dalam bekerja mampu memberikan pengaruh terhadap employee performance menjadi lebih baik. Sehingga walaupun career development di perusahaan kurang berjalan dengan baik, tidak akan memengaruhi employee performance. Seperti dalam wawancara terhadap salah satu pegawai BNI beliau mengungkapkan terdapat karyawan yang dari segi pekerjaan memiliki pelayanan lebih terhadap pelanggan menjadi kurang mendapat prioritas dalam mendapatkan promosi jabatan. Berdasarkan hasil wawancara tersebut dapat diketahui meskipun career development di perusahaan kurang objektif dalam promosi jabatan, employee performance tetap sesuai dengan KPI (Key Performance Indicator). Hasil dari penelitian ini mendukung penelitian dari Saputra \& Hendriani (2015), Diarini \& Budiartha (2018), Setiyaningrum, (2019), dan Putri \& Frianto (2019) serta Khotimah (2014) dan Pujiastuti (2019).

\section{Pengaruh Organizational Culture terhadap Job Satisfaction}

Berdasarkan penjelasan sebelumnya terkait hasil dari pengujian hipotesis terlihat nilai estimasi inner organizational culture terhadap job satisfaction menunjukkan hasil $\mathrm{H} 3$ diterima. Kemudian dari hasil wawancara online (by phone) terhadap beberapa karyawan perbankan di BRI, Bank Mandiri, BNI, dan BCA yang menunjukkan bahwa sistem organizational culture di perusahaan berjalan cukup baik, di mana antar karyawan maupun pimpinan saling membantu dan bekerjasama dalam menyelesaikan tugas dan kewajibannya serta apabila terdapat karyawan yang mengalami kesulitan akan terbantukan oleh karyawan atau rekan kerjanya. Sehingga organizational culture yang terjalin antar karyawan dalam pekerjaannya menimbulkan rasa puas dalam diri karyawan tersebut. Hal ini didukung dari pernyataan dari beberapa karyawan dari keempat bank tersebut yang menyatakan bahwa sudah merasa puas dengan rekan kerja yang senantiasa saling membantu dan bekerjasama dalam menyelesaikan tugas dan kewajibannya. Hasil dari penelitian ini diperkuat oleh Qazi \& Kaur (2017), Ilham (2017), Habib et al., (2014) dan Meng \& Berger (2019), Alvi et al., (2014), Zhang \& Li (2013) serta Alvi et al., (2014) dan Putriana et al., (2015).

\section{Pengaruh Organizational Culture terhadap Employee Performance}

Berdasarkan penjelasan sebelumnya terkait hasil dari pengujian hipotesis organizational culture terhadap employee performance menunjukkan bahwa H4 diterima. Berdasarkan hasil wawancara dengan beberapa karyawan perbankan BRI, Bank Mandiri, BNI, dan BCA menunjukkan bahwa sistem organizational culture di perusahaan berjalan cukup baik, di mana antar karyawan maupun pimpinan saling membantu dan bekerjasama dalam menyelesaikan tugas dan kewajibannya serta apabila terdapat karyawan yang mengalami kesulitan akan terbantukan oleh karyawan atau rekan kerjanya sehingga memengaruhi kinerja dari masing-masing karyawan dalam melaksanakan tugasnya. 
Johan Yuda Prawira Putra. Pengaruh Career Development dan Organizational Culture terhadap Job Satisfaction serta Dampaknya pada Employee Performance

Hasil ini mendukung Kahumburu et al., (2017), Batcha et al., (2017), dan Ugwu et al., (2017), Kawiana et al., (2018), Utari et al., (2018) serta Widjaja (2017) dan Nazir \& Zamir (2015).

\section{Pengaruh Job Satisfaction terhadap Employee Performance}

Berdasarkan penjelasan sebelumnya terkait hasil dari pengujian hipotesis job satisfaction terhadap employee performance menunjukkan bahwa $\mathrm{H} 5$ ditolak, sehingga diartikan tidak adanya pengaruh job satisfaction pada kondisi employee performance. Indikasi yang menyebabka tidak adanya pengaruh dari job satisfaction pada employee performance dimungkinan berupa aspek psikologis dalam diri masing-masing karyawan. Hal ini mengingat bahwa responden dalam penelitian ini merupakan karyawan perbankan dan sebagian besar berusia di bawah $\leq 30$ tahun sebanyak 37 orang $(97,4 \%)$ dari total 38 responden. Berdasarkan hasil wawancara terhadap beberapa karyawan perbankan di BRI, Bank Mandiri, BNI, dan BCA menyatakan bahwa rasa puas ataupun tidak, bukan merupakan sesuatu yang berarti dalam memengaruhi kinerja mereka karena sistem kerja yang sudah tertuang dalam SOP dan keterikatan kerja dengan perusahaan membuat karyawan harus tetap menjaga kinerja mereka. Hasil ini mendukung penelitian dari Hidayati \& Rahmawati (2016), Diarini \& Budiartha (2018), Arda (2017), dan Subakti (2013) serta Pawirosumarto et al., (2017), Putri, (2018), dan Hardiyanti (2018).

\section{Pengaruh Career Development terhadap Employee Performance melalui Job Satisfaction}

Berdasarkan hasil pengujian diketahui pengaruh tidak langsung career development terhadap employee performance melalui job satisfaction menunjukkan bahwa H6 ditolak. Sehingga dapat diartikan bahwa tidak adanya pengaruh indirect dari career development pada kondisi employee performance. Berdasarkan hasil wawancara terhadap beberapa karyawan perbankan menjelaskan ada beberapa faktor lain yang paling berpengaruh pada employee performance adalah seperti kerjasama tim, dedikasi dalam diri, loyalitas, dan komitmen dalam bekerja. Selain itu, dukungan yang diberikan oleh organisasi dalam bentuk seperti fasilitas pekerjaan dan tunjangan dalam bekerja mampu memberikan dampak. Hasil dari penelitian ini mendukung penelitian dari Diarini \& Budiartha (2018), Budy \& Hartini (2017), dan Putri (2018) serta Ningsih (2017).

\section{Pengaruh Organizational Culture terhadap Employee Performance melalui Job Satisfaction}

Berdasarkan hasil pengujian diketahui pengaruh tidak langsung organizational culture terhadap employee performance melalui job satisfaction menunjukkan bahwa H7 ditolak. Sehingga organizational culture tidak mempunyai pengaruh terhadap employee performance jika dimediasi job satisfaction. Hal ini dikarenakan organizational culture telah mempunyai dampak pada employee performance tanpa harus melalui job satisfaction dan terdapat faktor lain dan lebih dibutuhkan karyawan untuk dapat meningkatkan kinerja mereka. Berdasarkan hasil wawancara terhadap beberapa karyawan perbankan menjelaskan terdapat faktor lain yang paling berpengaruh pada kinerja, seperti kerjasama tim, dedikasi dalam diri, loyalitas, dan komitmen dalam bekerja. Selain itu, dukungan yang diberikan oleh organisasi dalam bentuk seperti fasilitas pekerjaan dan tunjangan dalam bekerja mampu memberikan dampak terhadap employee performance agar menjadi lebih baik. Hasil dari penelitian ini mendukung penelitian dari Pawirosumarto et al., (2017), Surahmat (2015), dan Hayuningtyas (2017) serta Wibowo (2018).

\section{KESIMPULAN}

Berdasarkan hasil penjelasan dan pengujian terhadap hipotesis yang diajukan dapat diketahui antara lain career deveopment berpengaruh positif terhadap job satisfaction, namun tidak berpengaruh terhadap employee performance di perbankan khususnya BRI, Bank Mandiri, BNI , dan BCA wilayah Jakarta Selatan. Selanjutnya ada pengaruh positif dari organizational culture pada job satisfaction dan employee performance di perbankan khususnya BRI, Bank Mandiri, BNI , dan BCA wilayah Jakarta Selatan. Sedangkan, job satisfaction tidak berpengaruh terhadap employee performance serta tidak berperan sebagai intervening antara career deveopment dan organizational culture terhadap employee performance di perbankan khususnya BRI, Bank Mandiri, BNI , dan BCA wilayah Jakarta Selatan.

Berdasarkan hasil tersebut dapat diberikan beberapa saran antara lain adalah menyarankan agar pimpinan dalam perusahaan dapat lebih objektif dalam menerapkan kebijakan terkait pemberian 
promosi jabatan dengan berdasarkan pada aspek kinerja. Hal tersebut dikarenakan agar tingkat kepercayaan setiap karyawan tinggi sehingga dapat meningkatkan job satisfaction. Selanjutnya disarankan juga agar perusahaan dapat mempertahankan dan mengoptimalkan organizational culture yang sudah diterapkan di perusahaaan. Hal ini juga dibuktikan dengan adanya pengaruh yang positif organizational culture pada employee performance dan job satisfaction. Selain itu, disarankan perusahaan membuat program yang mampu untuk meningkatkan dedikasi, loyalitas, dan komitmen karyawan dalam bekerja seperti memberikan reward, memberikan jenjang karir yang jelas, dan manajemen SDM yang lebih baik. Hal ini dikarenakan faktor-faktor tersebut mampu untuk memengaruhi employee performance. Kemudian jumlah sampel atau responden hanya terbatas pada 38 karyawan perbankan di BRI, Bank Mandiri, BNI, dan BCA wilayah Jakarta Selatan yang menarik untuk diteliti apabila jumlah responden besar, sehingga untuk penelitian berikutnya dianjurkan untuk menambah jumlah responden dan juga diharapkan untuk meneliti variabel lainnya yang juga dapat memengaruhi tingkat job satisfaction dan employee performance seperti seperti dedikasi, loyalitas, dan komitmen.

\section{DAFTAR PUSTAKA}

Alvi, A. H., Hanif, M., Adil, S. M., Ahmed, R. R., Vveinhardt, J., \& Professor, A. (2014). Impact of Organizational Culture on Organizational Commitment and Job Satisfaction. European Journal of Business and Management. 6(27): 2222-2839.

Ali, Z., Mahmood, B., \& Mehreen, A. (2019). Linking succession planning to employee performance: The mediating roles of career development and performance appraisal. Australian Journal of Career Development. 28(2): 112-121.

Alif, A. (2015). Pengaruh Motivasi Kerja, Pengembangan Karir dan Lingkungan Kerja terhadap Organizational Citizenship Behaviour (OCB) dengan Kepuasan Kerja sebagai Variabel Intervening Pada Perusahaan Terminal LPG. MIX: Jurnal Ilmiah Manajemen. 6(2): 291-309.

Andi, Sudarno, \& Nyoto. (2019). Pengaruh Budaya Organisasi, Motivasi Kerja, dan Komitmen Organisasi Terhadap Kepuasan Kerja dan Kinerja Karyawan PT. Arta Boga Cemerlang Pekanbaru. Jurnal Akuntansi, Kewirausahaan, Dan Bisnis. 4(1): 59-70.

Arda, M. (2017). Pengaruh Kepuasan Kerja Dan Disiplin Kerja Terhadap Kinerja Karyawan Pada Bank Rakyat Indonesia Cabang Putri Hijau Medan. Jurnal Ilmiah Manajemen Dan Bisnis. 18(1): 45-60.

Aritonang, K. L., Fadilah, N., Aritonang, T. A., \& Saragih, O. V. (2019). Pengaruh Pengembangan Karir dan Lingkungan Kerja Fisik terhadap Kepuasan Kerja Karyawan Pada PT. Sinar Sosro. Jurnal Manajemen. 5(1): 53-60.

Batcha, H. M., Jan, N. A., Subramani, A. K., \& Julie, R. L. (2017). Exploring the impact of organization culture on employees' work performance using structual equation modeling (SEM) approach. International Journal of Applied Business and Economic Research. 15(16): 483-493.

Bigliardi, B., Dormio, A. I., Galati, F., \& Schiuma, G. (2012). The impact of organizational culture on the job satisfaction of knowledge workers. Vine. 42(1): 36-51.

Budy, D. A., \& Hartini. (2017). Pengaruh Pengembangan Karir dan Lingkungan Kerja terhadap Kinerja Karyawan dengan Kepuasan Kerja sebagai Variabel Intervening pada Perusahaan SInjaraga Santika Sport. Media Studi Ekonomi. 20(1): 63-73.

Dewi, C. N. C., Bagia, I. W., \& Susila, G. P. A. J. (2014). Pengaruh Stres Kerja Dan Kepuasan Kerja 
Johan Yuda Prawira Putra. Pengaruh Career Development dan Organizational Culture terhadap Job Satisfaction serta Dampaknya pada Employee Performance

Terhadap Kinerja Karyawan Pada Bagian Tenaga Penjualan UD Surya Raditya Negara. EJournal Bisma Universitas Pendidikan Ganesha Jurusan Manajemen, 4(2): 154-161.

Diarini, I. G. A. A. S., \& Budiartha, I. G. D. (2018). Pengaruh Motivasi dan Pengembangan Karir Pada Kepuasan Kerja, Serta Dampaknya terhadap Kinerja Karyawan (Studi pada LPD Desa Adat Tegal). Jurnal Ilmiah Manajemen \& Akuntansi. 24(1): 87-106.

Fu, W., \& Deshpande, S. P. (2014). The Impact of Caring Climate, Job Satisfaction, and Organizational Commitment on Job Performance of Employees in a China's Insurance Company. Journal of Business Ethics. 124(2): 339-349.

Ghozali, I. (2013). Partial Least Square Konsep, Teknik dan Aplikasi SmartPLS 2.0. Semarang: Badan Penerbit Universitas Diponegoro.

Habib, S., Aslam, S., Hussain, A., Yasmeen, S., \& Ibrahim, M. (2014). The Impact of Organizational Culture on Job Satisfaction, Employess Commitment and Turn over Intention. Advances in Economics and Business. 2(6): 215-222.

Hadiwijaya, H. (2016). Effect of incentives and Career Development to Work Satisfaction through Performance of Employees as Variable Intervening (Case Study at PT. Smartfren Telecom Palembang). Prosiding Ekonomi \& Bisnis. (81587): 74-79.

Hardiyanti, E. S. (2018). Peran Intervening Kepuasan Kerja pada Pengaruh Disiplin Kerja dan Pengembangan Karir terhadap Kinerja Pegawai pada Fakultas Ekonomi dan Bisnis Universitas Sultan Ageng Tirtayasa. Tirtayasa Ekonomika. 13(2): 138-156.

Hasibuan, E. A., \& Afrizal. (2019). Analisis Pengaruh Kompetensi, Lingkungan Kerja, Dan Kompensasi Terhadap Kepuasan Kerja Dan Implikasinya Terhadap Kinerja Aparatur Sipil Negara. Jurnal Ekonomi Dan Manajemen. 5(1): 22-41.

Hayuningtyas, M. (2017). Peranan Kepuasan Karyawan dalam Memediasi Budaya Organisasi terhadap Kinerja Karyawan (Studi Kasus Pada PT Jasa Raharja (Persero) Cabang Bali). Jurnal Ekonomi \& Bisnis. 3(1): 39-53.

Syauta, H. J., Troena, A. E., \& Setiawan, M. (2012). The Influence of Organizational Culture, Organizational Commitment to Job Satisfaction and Employee Performance (Study at Municipal Waterworks of Jayapura, Papua Indonesia). International Journal of Business and Management Invention. 1(1): 2319-8028.

Hidayati, T., \& Rahmawati. (2016). The Effect on The Job Satisfaction Organization Performance of Employees Commitment, and Service Performance. Jurnal Ekonomi Dan Manajemen. 13(1): $1-12$.

Ilham, R. (2017). The Impact of Organizational Culture and Leadership Style on Job Satisfaction and Employee Performance. Journal of Advanced Management Science. 6(1): 50-53.

Jobplanet.com. (2016). Tingkat Kepuasan Karyawan Bank-bank Terbesar di Indonesia. (http://blog.id.jobplanet.com/tingkat-kepuasan-karyawan-bank-bank-terbesar-di-indonesia/. Diakses pada 2 Mei 2020).

Jufrizen. (2015). Pengaruh Kompensasi dan Pengembangan Karir terhadap Komitmen Organisasi dengan Kepuasan Kerja sebagai Variabel Intervening Pada PT. Perkebunan Nusantara III (Persero) Medan. Jurnal Ilmiah Manajemen Dan Bisnis. 15(01): 37-47. 
Jusuf, A. H., Mahfudnurnajamuddin, Mallongi, S., \& Latief, B. (2016). The Effect of Career Development, Leadership Style and Organizational Culture on Job Satisfaction and Organizational Commitment. International Journal of Business and Management Invention. 5(3): 07-17.

Kahumburu, N. N., Maru, L., \& Korir, M. (2017). Organizational Culture and Employee Performance in the Scripture Union of Kenya. Journal of Human Resource and Leadership. 1(2): 58-81.

Kawiana, I. G. P., Dewi, L. K. C., Martini, L. K. B., \& Suardana, I. B. R. (2018). The Influence of Organizational Culture, Employee Satisfaction, Personality, and Organizational Commitment Towards Employee Performance. International Research Journal of Management, IT and Social Sciences. 5(3): 35-45.

Kaya, C., \& Ceylan, B. (2014). An Empirical Study on The Role of Career Development Programs in Organizations and Organizational Commitment on Job Satisfaction of Employees. American Journal of Business and Management. 3(3): 178-191.

Khan, M. M., Rehman, Z., \& Akram, M. W. (2012). The impact of employee commitment on employee satisfaction role of employee performance as a moderating variable. Singaporean Journal of Business Economics, and Management Studies. 1(2): 68-80.

Khotimah, K. (2014). Pengaruh Kepemimpinan dan Pengembangan Karir pada Kepuasan Kerja serta Dampaknya terhadap Kinerja Karyawan. Jurnal Ilmu Manajemen. 2(2): 660-674.

Luthans, F. (2011). Organizational Behavior. An Evidence-Based Approach (12th ed.). New York: MacGraw-Hill International Edition.

Maghfiroh, L., \& Djati, S. P. (2017). Pengaruh Pengembangan Karir, Kompensasi dan Motivasi terhadap Kepuasan Kerja Karyawan di PT. Alun Alun Indonesia Kreasi. Jurnal SWOT. 7(3): $542-558$.

Manoppo, R. (2015). Pengaruh Displin Kerja, Motivasi Kerjadan Pengembangan Karir Terhadap Kepuasan Kerja Pada Tvri Sulawesi Utara. Jurnal Riset Ekonomi, Manajemen, Bisnis Dan Akuntansi. 3(3): 1220-1231.

Maslichah, N. I. (2017). Pengaruh Work Life Balance dan Lingkungan Kerja terhadap Kepuasan Kerja Karyawan ( Studi pada Perawat RS Lavalette Malang Tahun 2016 ). Jurnal Administrasi Bisnis. 49(1): 60-68.

Mathis, R. L., \& Jackson, J. H. (2008). Human Resource Management, Twelfth Edition. United States Of America: Thomson South-Western, A Part Of The Thomson Corporation.

Meng, J., \& Berger, B. K. (2019). The impact of organizational culture and leadership performance on PR professionals' job satisfaction: Testing the joint mediating effects of engagement and trust. Public Relations Review. 45(1): 64-75.

Nasution, M. F., Mariatin, E., \& Zahreni, S. (2018). The Influence of Career Development and Organizational Culture on Employee Performance. International Journal of Scientific Research and Management. 6(01): 57-65.

Nazir, N., \& Zamir, S. (2015). Impact of Organizational Culture on Employee Performance. Industrial Engineering Letters. 5(9): 31-37.

Ningsih, N. F. L. (2017). Pengaruh Pengembangan Karir terhadap Kinerja Karyawan melalui 
Johan Yuda Prawira Putra. Pengaruh Career Development dan Organizational Culture terhadap Job Satisfaction serta Dampaknya pada Employee Performance

Kepuasan Keja Pada PT. PLN (Persero) Rayon Lamongan. Skripsi. Malang: Universitas Islam Negeri Maulana Malik Ibrahim.

Nurendra, Annisa, M., \& Saraswati, Mega, P. (2016). Model Peranan Work Life Balance, Stres Kerja, dan Kepuasan Kerja pada Karyawan. Indonesian Psychological Journal. 13(2): 84-94.

Nusari, M., Falasi, A. M., Alrajawy, I., Khalifa, G. S., \& Isaac, O. (2018). Impact of Organizational Culture on Employee Performance. International Journal of Management and Human Science. 2(3): 15-26.

Pawirosumarto, S., Sarjana, P. K., \& Gunawan, R. (2017). The Effect of Work Environment, Leadership Style, and Organizational Culture towards Job Satisfaction and its Implication towards employee performance in Parador Hotels and Resorts, Indonesia. International Journal of Law and Managemen. 59(6): 1337-1358.

Pujiastuti, E. N. (2019). Pengaruh Pengembangan Karir dan Kepemimpinan Transformasional terhadap Kinerja Karyawan dengan Loyalitas Kerja sebagai Variabel Mediasi (Studi Empiris Pada Karyawan Universitas Muhammadiyah Magelang). Skripsi. Magelang: Universitas Muhammadiyah Magelang.

Putra, A. A. G., Dharmanegara, I. B. A., \& Yas, P. N. S. (2019). Analyzing the Relationship of Ethical Work Climate, Job Satisfaction, Organizational Commitment and Job Performance in Tabanan University, Bali. International Journal of Academic Research in Business and Social Sciences. 9(9): 1100-1115.

Putri, G. R. (2015). Pengaruh Karakteristik Pekerjaan, Pengembangan Karir dan Stres Kerja Pada Komitmen Organisasional Bagi Karyawan PDAM Tirta Moedal Kota Semarang. Skripsi. Semarang: Universitas Negeri Semarang.

Putriana, L., Wibowo, Umar, H., \& Riady, H. (2015). The Impact of Organizational Culture On Job Satisfaction, Organizational Commitment And Job Performance: Study on Japanese Motorcycle Companies in Indonesia. International Journal of Education and Research. 3(9): $103-114$.

Putri, S. E. (2018). Pengaruh Lingkungan Kerja dan Pengembangan Karir Terhadap Kinerja Karyawan dengan Kepuasan Kerja sebagai Variabel Intervening (Studi Kasus pada PT Telkom Witel Yogyakarta). Skripsi. Yogyakarta: Universitas Islam Indonesia.

Qazi, S., \& Kaur, T. (2017). Impact of Organizational Culture on Job Satisfaction among the University Faculty Members-An Empirical Study. International Journal of Business and Social Science. 8(3): 171-178.

Rahmi, A., \& Mulyadi. (2018). Pengaruh Keterlibatan Karyawan, Budaya Organisasi dan Kepemimpinan Transformasional terhadap Komitmen Organisasional Karyawan pada PT. PLN Banda Aceh Amelia. Jurnal Ilman. 6(1): 68-76.

Robbins. (2002). Prinsip-Prinsip Perilaku Organisasi (Edisi Keli). Jakarta: Erlangga.

Robbins, S. P., \& Judge, T. A. (2015). Perilaku Organisasi (16th ed.). Jakarta: Salemba Empat.

Rehman, S. U., Qingren, C., Latif, Y., \& Iqbal, P. (2017). Impact of Psychological Capital on Occupational Burnout and Performance of Faculty Members. International Journal of Educational Management. 31(4): 455-469. 
Saleem, Y., Kamran, M. R., Sabir, F., \& Iqbal, J. (2013). Career Development an Imperative of Job Satisfaction and Career Commitment: Empirical Evidence from Pakistani Employees in Banking Sector. Europan Journal of Business and Management. 5(21): 108-118.

Saputra, A. R., \& Hendriani, S. (2015). Pengaruh Kompetensi, Komitmen dan Pengembangan Karir Terhadap Kinerja Karyawan PT.Bank Rakyat Indonesia (Persero) Kantor Wilayah Pekanbaru. Jurnal Tepak Manajemen Bisnis. 7(1): 1-17.

Sari, O. R., \& Susilo, H. (2018). Pengaruh Kepuasan dan Motivasi Kerja terhadap Kinerja Karyawan dengan Organizational Citizenship Behavior $(\mathrm{Ocb})$ sebagai Variabel Intervening (Studi pada Karyawan PTPN X-Unit Usaha Pabrik Gula Modjopanggong Tulungagung). Jurnal Administrasi Bisnis. 64(1): 28-35.

Sashkin, M., \& Rosenbach, W. E. (2013). Organizational Culture Assessment Questionnaire. International \& Pan-American Copyright Conventions: Marshall Sashkin.

Sathyanarayan, K., \& Lavanya, B. L. (2018). Effect of Organizational Commitment, Motivation, Attitude Towards Work on Job Satisfactin, Job Performance and Turnover Intention-VUCA Perspective. Journal of Management. 5(4): 445-457.

Setiyaningrum, A. C. (2019). Pengembangan Karir Terhadap Kinerja Karyawan Melalui Kepuasaan Kerja Sebagai Variabel Intervening. Jurnal Ilmu Manajemen. 7(3): 824-831.

Shujaat, S., Sana, S., Aftab, F., \& Ahmed, I. (2013). Impact of Career Development on Employee Satisfaction in Private Banking Sector Karachi. Journal of Management and Social Sciences. 9(2): $1-8$.

Siregar, S. (2017). Statistik Parametrik untuk Penelitian Kuantitatif: dilengkapi dengan perhitungan manual dan aplikasi SPSS versi 17 (Edisi 1). Jakarta: Bumi Angkasa.

Subakti, A. G. (2013). Pengaruh Motivasi, Kepuasan, dan Sikap Kerja terhadap Kinerja Karyawan di Café X Bogor. Binus Business Review. 4(2): 596.

Sulaiman, Asnawi, \& Matriadi, F. (2014). Pengaruh Pemberdayaan, Self Efficacy dan Budaya Organisasi terhadap Kinerja Karyawan PT. Surya Madistrindo Cabang Lhokseumawe dengan Kepuasan Kerja sebagai Variabel Intervening. Jurnal Ekonomi, Manajemen Dan Akuntansi. 4(1): 1-11.

Sutrisno, E. (2009). Manajemen Sumber Daya Manusia (Edisi Pert). Jakarta: Kencana.

Surahmat, A. (2015). Pengaruh Kemampuan Kerja, MotivasiI, dan Budaya Organisasi terhadap Kinerja melalui Kepuasan Kerja Pegawai Dinas Perhubungan, Komunikasi dan Informatika Kabupaten Pati. Skripsi. Kudus: Universitas Muria Kudus.

Suryadani, S. A. (2016). Pengaruh Pengembangan Karir terhadap Kinerja Karyawan Divisi Konstruksi IV PT. Adhi Karya (Persero) Tbk. Surabaya. Jurnal Ilmu Manajemen. 4(3): 1-10.

Utari, A. T., Rival, A., \& Silitonga, P. E. S. (2018). Influence of Leadership and Organizational Culture on Performance through Motivation in PT. Bank Rakyat Indonesia Tbk Branch of Bekasi. International Journal of Business and Applied Social Science. 4(7): 57-69.

Veithzal, R., \& Sagala, E. (2011). Manajemen Sumber Daya Manusia untuk Perusahaan (Kedua). Jakarta: PT. Rajagrafindo Persada. 
Johan Yuda Prawira Putra. Pengaruh Career Development dan Organizational Culture terhadap Job Satisfaction serta Dampaknya pada Employee Performance

Wibowo, R. (2018). Pengaruh Budaya Organisasi dan Komitmen Organisasi terhadap Kinerja Karyawan dengan Kepuasan Kerja sebagai Variabel Intervening di Lembaga Pendidikan Islam Terpadu Bina Anak Sholeh (LPIT BIAS). Skripsi. Yogyakarta: Universitas Islam Indonesia.

Widjaja, A. (2017). Impacts of Organizational Culture, Emotional Intelligence, and Communication Competence on Employee Performance. International Journal of Applied Business and Economic Research. 15(23 (Part 2)): 67-78.

Putri, W. A., Frianto, A. (2019). Pengaruh Pengembangan Karier Terhadap Motivasi dan Dampaknya Terhadap Kinerja Karyawan (Studi Kasus di PT. Barata Indonesia (Persero) Gresik). Jurnal Ilmu Manajemen. 7(2): 1-10.

Zhang, X., \& Li, B. (2013). Organizational Culture and Employee Satisfaction: An Exploratory Study. International Journal of Trade, Economics and Finance. 4(1): 48-54. 